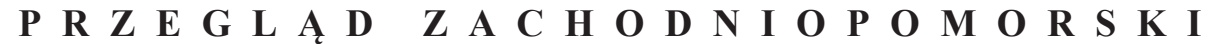 ROCZNIK XXXI (LX) ROK 2016 ZESZYT 1
}

$\begin{array}{lllllllllllllll}\mathbf{S} & \mathbf{T} & \mathbf{U} & \mathbf{D} & \mathbf{I} & \mathbf{A} & \mathbf{I} & \mathbf{R} & \mathbf{O} & \mathbf{Z} & \mathbf{P} & \mathbf{R} & \mathbf{A} & \mathbf{W} & \mathbf{Y}\end{array}$

AnNa MichaŁeK-SimińsKa

Szczecin

\section{ZNACZENIE KORONACJI KRÓLEWSKIEJ W PóźnośredNIOWIECZneJ FrancJi}

Słowa kluczowe: koronacja, Francja, późne średniowiecze

Keywords: coronation, France, the late Middle Ages

W XIV i XV wieku w monarchii francuskiej coraz większe znaczenie zyskiwały ceremonie z udziałem króla, najwyższych dostojników i ludu ${ }^{1}$. Obok uroczystości zaślubin, narodzin i chrztów dzieci królewskich czy też pogrzebów władców, należy wśród nich wymienić królewskie koronacje ${ }^{2}$ i uroczyste wjazdy króla do

\footnotetext{
${ }^{1}$ Szeroka i różnorodna problematyka dotycząca królewskich ceremonii była przedmiotem licznych opracowań, zob. m. in. E. Kantorowcz, Laudes regiae. A Study in Liturgical Acclamations and Mediaeval Rulers Worship, Berkeley 1946; tenże, Dwa ciała króla. Studium ze średniowiecznej teologii politycznej, red. wyd. pol. J. Strzelczyk, Warszawa 2007, passim; G. Fouquet, H. von Seggern, G. Zeilinger, Höfische Feste im Spätmittelalter. Eine Einleitung, w: Höfische Feste im Spätmittelalter, hrsg. v. G. Fouquet, H. von Seggern, G. Zeilinger, Kiel 2003 (Mitteilungen der Residenzen-Kommission der Akademie der Wissenschaften zu Göttingen, Sonderheft 6), s. 9-18. Ciekawe uwagi na temat średniowiecznych ceremonii zawarte zostały we wstępie pracy: L'État ou le roi. Les fondation de la modernité monarchique en France (XIV ${ }^{e}-X V I I^{e}$ siècles), éd. N. Bulst, R. Descimon, A. Guerreau, Paris 1996, s. 3. Dla okresu nowożytnego zob. W. Krawczuk, Kancelaria koronna a ceremoniat dworski, w: Theatrum ceremoniale na dworze książat i królów polskich. Materiały z konferencji naukowej zorganizowanej przez Zamek Królewski na Wawelu i Instytut Historii Uniwersytetu Jagiellońskiego w dniach 23-25 marca 1998, red. M. Markiewicz, R. Skowron, Kraków 1999, s. 183-191.

2 J. Le Goff, Reims, ville du sacre, w: Les lieux de mémoire, t. 2: La nation, sous la dir. de P. Nora, Paris 1986, s. 89-184.
} 
miast (les entrées royales, adventus regis) ${ }^{3}$. W późnym średniowieczu zmieniło się jednak znaczenie tych wydarzeń. Ściśle związane z nimi ceremoniał i liturgia były przesycone treściami ideologicznymi ${ }^{4}$. „Jeżeli procesjonalny wjazd monarszy (średniowieczny adventus regis) zawiera sporo składników świeckich, nawet ludycznych, a jego nazwa starofrancuska, la joyeuse entrée, przesłania, choć bynajmniej nie całkowicie, kontakt z sacrum, to pogrzeb, a zwłaszcza koronacja są także, a nawet przede wszystkim - liturgią".

Koronacja królewska miała fundamentalne znaczenie dla legitymizacji władzy króla; była sposobem manifestacji jej ciągłości. Ceremonia ta zawierała elementy, które służyły ugruntowaniu w ówczesnym społeczeństwie przekonania o pomyślności domu panującego. Tak rozumiany problem zostanie omówiony w odniesieniu do sfery sakralnej, prawa stanowionego i świadomości społecznej ${ }^{6}$.

\footnotetext{
${ }^{3}$ Wybrane prace dotyczące wjazdów królewskich: Th., D. Godefroy, Le cérémonial françois, Paris 1649; L. Petit de Julleville, Les mystères, t. 1, Paris 1880, s. 192-194; J. Chartrou, Les entrées solennelles et triomphales à la Renaissance (1484-1551), Paris 1928; J. Jacquot, La fête princière, w: Histoire des spectacles, Encyclopédie de la Pléiade, Paris 1965, s. 211-213, 215-223; J. Heers, Fêtes, jeux et joutes dans les sociétés d'Occident à la fin du Moyen Âge, Paris 1971; G. Balandier, Le pouvoir sur scènes, Paris 1980; B. Guenée, F. Lehoux, Les Entrées...; L.M. Bryant, La cérémonie de l'entrée à Paris au Moyen Âge, „Annales. Économies, Sociétés, Civilisations”, 3, mai-juin 1986, s. 513-542; tenże, The King and the City in the Parisian Royal Entry Ceremony: politics, ritual, and art in the Renaissance, Genève 1986; tenże, The medieval entry ceremony at Paris, w: Coronations. Medieval and Early Modern Ritual, ed. J.M. Bak, Berkley-Los Angeles-Oxford 1990, s. 88-113; Ch. de Mérindol, Entrées royales et princière à la fin de l'époque médiévale: jeux de taxinomie, d'emblématique et de symbolique, w: Les entrées gloire et déclin d'un cérémonial. Actes du colloque tenu au château de Pau les 10 et 11 mai 1996, sous la présidence du Professeur Bernard Guenée, actes réunis par Christian Desplat et Paul Mironneau, Paris 1998, s. 27-47; H. Martin, Mentalités médiévales Représenations collectives du XI au XVe siècle, t. 2, Paris 2001, s. 141 i n. Ostatnio na temat uroczystych wjazdów władców niemieckich G.J. Schenk, Zeremoniell und Politik. Herrschereinzüge im spätmittelalterlichen Reich, Köln-Weimar-Wien 2003 (Forschungen zur Kaiser- und Papstgeschichte des Mittelalter. Beihefte zu J.F. Böhmer, „Regesta Imperii", 21).

${ }^{4} \mathrm{Na}$ ten temat U. Borkowska, Królewskie zaślubiny, narodziny i chrzest, w: Imagines potestatis. Rytuaty, symbole i konteksty fabularne władzy zwierzchniej w Polsce X-XV w. (z przykładem czeskim i ruskim), red. J. Banaszkiewicz, Warszawa 1994, s. 75-92; taż, Codzienny i odświętny ceremoniat religijny na dworze Jagiellonów, w: Theatrum ceremoniale..., s. 61-85 (szczególnie s. 61-63).

${ }^{5}$ A. Gieysztor, Spektakl i liturgia - polska koronacja królewska, w: Kultura elitarna i masowa w Polsce późnego średniowiecza, red. B. Geremek, Wrocław 1978, s. 9.

${ }^{6} \mathrm{~W}$ historiografii polskiej znakomitym przykładem takiego schematu narracyjnego jest tekst Andrzeja Pleszczyńskiego poświęcony koronacjom królów niemieckich - Powołanie i koronacja króla niemieckiego od X do XIII wieku. Miejsca, ryty, insygnia-zarys problemu, w: Gnieźnieńskie koronacje królewskie i ich środkowoeuropejskie konteksty, red. J. Dobosz, M. Matla, L. Wietesko, Gniezno 2011 („Colloquia Mediaevalia Gnesnensia” II, s. 59-73). Podstawowe uwagi na temat zagadnienia koronacji zebrał J.M. Bak, Introduction. Coronation studies - past, present, and future,
} 
Historia badań nad ceremonią koronacji władców francuskich ma długą tradycję. Poznanie szeregu związanych z nią aspektów umożliwiają obficie zachowane źródła. Wśród nich należy wskazać ordines koronacyjne oraz źródła narracyjne. Pozwalają one $-z$ jednej strony - na odtworzenie przebiegu ceremonii koronacyjnych, z drugiej zaś pokazują ich znaczenie dla ówczesnej opinii publicznej. Celem prezentowanego studium jest rozpatrzenie znaczenia ceremonii koronacyjnej z punktu widzenia legitymizacji władzy królów francuskich na przełomie XIV i XV wieku. W pierwszej części omówione zostaną zagadnienia związane z refleksją średniowiecznych teoretyków państwa nad pojęciem korony francuskiej w powiązaniu z ceremonią koronacyjną. Przedmiotem drugiej części będzie zaś sam przebieg ceremonii. Rozpatrzone zostanie znaczenie takich jej elementów, jak miejsce, wykonawcy oraz regalia.

Z punktu widzenia rozpatrywanego problemu niezwykle ważne jest zagadnienie podwójnego charakteru władzy monarszej. Dyskutowano nad nim przez okres całego średniowiecza. Z jednej strony król był traktowany jako osoba świec$\mathrm{ka}, \mathrm{z}$ drugiej zaś był quasi-kapłanem? ${ }^{7}$. W liturgii pojawiła się tendencja zmierzająca nie tyle do zaprzeczania kapłańskiemu charakterowi instytucji monarchii, co do pomniejszania jego znaczenia. W XIII wieku, we Francji, namaszczenie królewskie przestało być traktowane jako jeden z sakramentów, jednak tendencja upodabniania królewskiej sakry do święceń kapłańskich trwała nadal i była rozwijana oraz modyfikowana zarówno przez kolejnych monarchów, jak i przedstawicieli władz świeckich, czy wreszcie samych teoretyków monarchii. W doktrynie politycznej powstającej na użytek poddanych w środowiskach dworskich, władca nie był nigdy traktowany jedynie jako osoba świecka. Z czasem doszło do powstania przekonania, że królestwo może popaść w zbyt dużą zależność od sankcji udzielanej mu przez Kościół ${ }^{8}$. W rezultacie, w XIII stuleciu, na obszarze Rzeszy Niemieckiej, szczególnie w okresie „wielkiego bezkrólewia”, rozwinięto teorię, że król otrzymuje pełnię władzy w spadku, w wyniku śmierci poprzednika lub w wyniku elekcji, w momencie jego wyboru. W takim wypadku, koronacja

w: Coronations..., s. 1-10. Zob. także G. Klaniczay, Źródła, formy i dziedzictwo sakralnego charakteru godności królewskiej w Europie, w: Świat średniowiecza. Studia ofiarowane Profesorowi Henrykowi Samsonowiczowi, red. A. Bartoszewicz i in., Warszawa 2010, s. 552-576.

${ }^{7}$ M. Bloch, Królowie cudotwórcy. Studium na temat nadprzyrodzonego charakteru przypisywanego władzy królewskiej zwłaszcza we Francji i w Anglii, tłum. J.M. Kłoczowski, Warszawa 1998, s. 173 i n.

${ }^{8}$ Tamże, s. 196. 
jest jedynie aktem dopełniającym zaistniały fakt, ale nie jest niezbędna9. Podobnie samo namaszczenie przestało być niezbędne do posiadania pełni królewskiej władzy. Przekonanie, że sakra nie czyniła królem, i że „królem można być bez sakry i jest się nim przed sakrą", rozwijano także w kolejnych stuleciach w innych państwach ${ }^{10}$. Pogląd taki głosili m.in. francuscy pisarze polityczni, tacy jak Jan z Paryża w czasach Filipa Pięknego czy też Jean Gerson ${ }^{11}$. W kręgu doradców Karola V propagowano pogląd, że królowie zdobywają władzę poprzez prawo krwi, że król sam z siebie obdarzony jest cechami nadludzkimi, które Kościół musi uznać. Autor Songe du Verger, utworu powstałego za panowania i z inspiracji tego władcy, uważał, że sakra nie jest źródłem cudownej władzy monarchy ${ }^{12}$.

Ernst Kantorowicz zwracał uwagę, że we Francji nastąpił wzrost znaczenia zasady sukcesji dynastycznej. Uważano że „sukcesja tronu jest przyrodzonym prawem najstarszego syna: $\mathrm{z}$ chwilą śmierci albo pogrzebu panującego monarchy jego syn lub prawny następca automatycznie zostawał królem”. Dla przykładu, panowanie króla rozpoczynało się w Anglii po 1308 roku dzień po śmierci poprzednika ${ }^{13}$. Teoria ta odpowiadała potrzebom politycznym, miała bowiem fundamentalne znaczenie dla monarchii, szczególnie w okresie między śmiercią króla a wyborem następcy, kiedy istniało największe zagrożenie związane z bezkrólewiem. We Francji przełomowym momentem był rok 1270, na który przypadł początek panowania Filipa III, syna Ludwika IX. Kiedy Filip dowiedział się o śmierci ojca, przebywał w Tunisie. Nie czekając na koronację, której nie można było dokonać w najbliższym czasie, przyjął tytuł królewski i rozpoczął rządy jako pełnoprawny władca. Sakry Filipa III dokonano dopiero w rok po śmierci jego ojca ${ }^{14}$. W kancelarii królewskiej Filipa III pojawiła się innowacja, polegająca na tym, że w dokumentach za początek panowania nowego króla przyjmowano datę śmierci poprzednika, a precyzyjniej - dzień po jego śmierci lub datę

${ }^{9}$ O poglądach teoretyków w tej kwestii, E.H. Kantorowicz, Dwa ciała króla..., s. 259 i n.

${ }^{10}$ M. Bloch, Królowie cudotwórcy..., s. 197.

${ }^{11}$ Zob. E.H. Kantorowicz, Dwa ciała króla..., s. 260.

12 J. Barbey, Etre roi. Le roi et son gouvernement en France de Clovis à Louis XVI, Paris 1992, s. 39; A. Leguai, Fondements et problèmes du pouvoir royal en France (autour de 1400), w: Das spätmittelalterliche Königtum im europäischen Vergleich, hrsg. v. R. Schneider, Sigmaringen 1987 (Vorträge und Forschungen Konstanzer Arbeitskreis für mittelalterliche Geschichte, 32), s. 49.

${ }^{13}$ E.H. Kantorowicz, Dwa ciała króla..., s. 254, 263, 268.

${ }^{14}$ J. Krynen, L'Empire du roi. Idées et croyances politiques en France XIII-XV siècle, Paris 1993, s. 138. 
jego pogrzebu, a nie dzień sakry ${ }^{15}$. Podobnie, w Anglii w XIII wieku, wbrew panującemu zwyczajowi, król Edward I liczył panowanie nie od koronacji, ale od objęcia władzy w 1272 roku. W obu przypadkach wprowadzono w życie nauki jurystów. W sferze prawnej zachowano w ten sposób ciągłość władzy i uniknięto okresu bezkrólewia. Rzeczywistym powodem takiego postępowania królów były jednak przede wszystkim względy praktyczne ${ }^{16}$. Zmiana przekonania widoczna była w królewskiej administracji. Panowanie Filipa Walezjusza datowane jest na moment, kiedy jego poprzednik Karol został pochowany w Saint-Denis, a z kolei panowanie Jana II - w dniu pogrzebu Filipa Walezjusza. Natomiast Karol V i Karol VI rozpoczęli rządy w dniu śmierci swoich poprzedników ${ }^{17}$.

Ordonans wydany za panowania Karola V, w sierpniu 1374 roku, poruszał kwestię przekazywania władzy królewskiej we Francji. Zawierał on następujące postanowienia w tej sprawie: najstarszy syn zmarłego króla dziedziczy po nim tron; w przypadku braku syna dziedziczy najbliżej spokrewniony z królem jego męski potomek; kobiety są wykluczone z sukcesji tronu; nie mogą również przekazywać prawa do korony, gdyż same go nie mają - tzn. nie dziedziczy się przez kobietę; wyklucza się elekcyjność tronu francuskiego; najbliższy męski dziedzic obejmuje tron z chwilą śmierci ojca (czyli jest królem od momentu śmierci poprzednika), a jego prawo do sakry w Reims nie może być kontestowane ${ }^{18}$. W kilkadziesiąt lat później legiści francuscy (Piotr Jacobi) uważali, że w okresie między śmiercią monarchy francuskiego Ludwika X w 1316 roku a narodzinami jego syna Jana I Pogrobowca, istniała ciągłość sukcesyjna. Mimo iż dziecko przeżyło tylko pięć dni i nie zostało koronowane, uznano je za pełnoprawnego króla ${ }^{19}$.

${ }^{15}$ P.E. Schramm, Der König von Frankreich: Wahl, Krönung, Erbfolge und Königsidee vom Anfang der Kapetinger (987) bis zum Ausgang des Mittelalters (Fortsetzung und Schluß) (Zeitschrift der Savigny Stiftung für Rechtsgeschichte Kanonistische Abteilung, 26, 1937), s. 273-274; M. Bloch, La France sous les derniers Capétiens 1223-1328, Paris 1958, s. 17; tenże, Królowie cudotwórcy..., s. 197; M. Valensise, Le sacre du roi: stratégie symbolique et doctrine politique de la monarchie française, „Annales. Économies, Sociétés, Civilisations”, 3, mai-juin 1986, s. 549, 573, przypis 8; A. Leguai, Fondements et problèmes..., s. 49.

${ }^{16}$ E.H. Kantorowicz, Dwa ciała króla..., s. 263.

${ }^{17}$ J. Krynen, „Le mort saisit le vif”. Genèse médiévale du principe d'instantanéité de la succession royale française, „Journal des Savants”, juillet-décembre 1983, s. 203.

${ }^{18}$ R. Cazelles, Société politique, noblesse et couronne sous Jean le Bon et Charles V, GenèveParis 1982, s. 580-581.

${ }^{19}$ A. Rigaudière, État, pouvoir et administration dans la Practica aurea libellorum de Pierre Jacobi (vers 1311), w: Droits savants et pratiques françaises du pouvoir (XIe $-X V^{e}$ siècle), éd. J. Krynen, A. Rigaudière, Bordeaux 1992 s. 171-173. 
Zachowane rachunki królewskie z pogrzebu Jana I oraz dokumenty z okresu panowania Filipa VI Walezjusza nazywają Jana I królem. Także autor Wielkich Kronik Francji określał go „królem” lub „królem bez imienia”20. W świadomości królów obejmowali oni władzę na wieść o zgonie ojca. O śmierci Jana II jego syn Karol dowiedział się 16 kwietnia, natomiast nazajutrz wydał akt, w którym tytułował siebie po raz pierwszy królem ${ }^{21}$. Według oficjalnych kronik dworskich, nowy władca rozpoczynał panowanie tuż po zakończeniu uroczystości pogrzebowych dotychczasowego króla. Stało się tak w przypadku Filipa IV Pięknego i Jana II Dobrego. W rejestrach „Chambre des comptes” początek panowania Jana II jest datowany od chwili pochówku Filipa Walezjusza, natomiast początek panowania Karola V i jego syna Karola VI od dnia śmierci poprzednika ${ }^{22}$. Inaczej inaugurację panowania Karola $\mathrm{V}$ przedstawiały kroniki. Do momentu pogrzebu swojego ojca był on określany jako najstarszy syn króla, książę Normandii, regent i delfin ${ }^{23}$. W Wielkich Kronikach Francji dopiero od chwili złożenia zwłok jego ojca w grobie nazywany był królem ${ }^{24}$. Raymond Cazelles podkreślił jednak, że autor oficjalnej Chronique des règnes de Jean II et de Charles V, opisując pogrzeb króla Jana II, nadal nazywał jego syna Karola V księciem Normandii, a podczas mszy pogrzebowej, królem i najstarszym synem („le roy Charles, son ainsné fils" ${ }^{25}$. Karol V na pogrzebie swojego ojca nazywany był księciem Normandii, a dopiero po jego zakończeniu tytułowano go królem („le roy Charles”)26. Następnie na kartach wspomnianej kroniki odnotowano, że król udał się na koronację do Reims. Wart podkreślenia jest fakt, że jeszcze przed sakrą występował

\footnotetext{
${ }^{20}$ J. Barbey, Etre roi..., s. 38.

${ }^{21}$ Chronique des règnes de Jean II et de Charles V, éd. R. Delachenal, t. 1, Paris 1910, s. 341, przypis 2 .

22 J. Krynen, L'Empire du roi..., s. 147.

${ }^{23}$ „Charles, ainsné filz du roy de France, régent le royaume, duc de Normandie et daulphin de Viennois”, „Charles, son ainsné filz, lors duc de Normandie et daulphin de Viennoys”, Chronique des règnes de Jean II et de Charles V..., s. 300, 341, 343-344. Por. także podobnie w Chronique latine de Guillaume de Nangis de 1113 à 1300, avec les continuations de cette chronique de 1300 à 1368, éd. H. Géraud, t. 2, Paris 1863, s. 333, 339-340, 344; Chronique normande du XIV siècle, éd. A., E. Molinier, S.H.F., Paris 1882, s. 96.

24 „Et tantost après la messe, le roy Charles, son ainsné filz, ala ou preau du cloistre de la dicte eglise, et là, appoyé à u savigner (...)", Chronique des règnes de Jean II et de Charles V..., s. 344; A. Leguai, Fondements et problèmes..., s. 49.

${ }^{25}$ R. Cazelles, Société politique..., s. 459.

${ }^{26}$ Chronique des règnes de Jean II et de Charles V, t. 1, s. 344: „Et tantost après la messe, le roy Charles, son aisné filz (...)"; R. Delachenal, Histoire de Charles V..., t. 3, Paris 1916, s. 22.
} 
jako „król”27. Mnich z Saint Denis za początek panowania Karola VI przyjął rok śmierci jego ojca i pisał o nim od tej chwili jako o „nowym królu Francji” („,dominus Karolus novus rex Franciae"). Koronacja jawi się więc jako konieczna w procedurze dopełnienia czynności służących przejęciu władzy w państwie, a samo prawo primogenitury - niewystarczające ${ }^{28}$.

Takie rozróżnienie spowodowało, że istnienie dynastii i ciągłość władzy królewskiej została uniezależniona od czasu, który nie działał już na niekorzyść dynastii ${ }^{29}$. Samo narodzenie dziedzica było uważane za zrządzenie boskie. Dzięki prawu krwi miało ono automatycznie stać się następcą ${ }^{30}$. Y.-M. Bercé zauważył, że we Francji następca nie uczestniczył w ceremonii pogrzebowej poprzednika, gdyż mogłoby dojść do konfliktu między czcią, jaką oddawano zmarłemu, i tą należną nowemu królowi ${ }^{31}$. Badacz przypomniał również, że w 1380 roku na pogrzebie Karola V o nieobecności następcy zdecydował przypadek. W następnym stuleciu stało się to już praktyką. Reguły następstwa zawierały się w maksymie „le mort saisit le vif”, która oznaczała, że w momencie śmierci króla jego sukcesor otrzymywał pełnię praw, którymi dysponował dotąd zmarły. Następca stawał się królem w momencie śmierci poprzednika ${ }^{32}$.

Legitymizacja króla miała charakter dynastyczny, niezależny od aprobaty czy konsekracji kościelnej, bowiem władza pochodziła od Boga. Pojawiło się rozróżnienie między materialną koroną używaną podczas koronacji i niematerialną, niewidzialną Koroną obejmującą wszystkie prawa i przywileje królewskie konieczne do rządzenia wspólnotą. Drugie rozumienie pojęcia Korona oznaczało

${ }^{27}$ Chronique des règnes de Jean II et de Charles V..., t. 1, s. 345: „Item, le jeudy ensuyvant, IX jour du dit mois de may, parti le dit roy Charles de Saint-Denis pour aller à son sacre à Reims, le quel devoit estre le jour de la Trinité ensuyvant".

${ }^{28}$ Chronique du Religieux de Saint-Denys contenant le règne de Charles VI de 1380 à 1422, publiée en latin et traduite par M.L. Bellaguet, vol. 1-6, Paris 1839-1852; reproduite avec une introduction de Bernard Guenée en trois tomes contenant chacun deux volumes, Paris 1994 (dalej: RSD), t. 2, s. 685 ; t. 6 , s. 3 .

${ }^{29}$ E.H. Kantorowicz, Dwa ciała króla..., s. 134, 263.

30 Tamże, s. 264.

${ }^{31}$ Y.-M. Bercé, Le roi caché. Sauveurs et imposteurs. Mythes politiques populaires dans l'Europe moderne, Paris 1990, s. 386-387.

32 J. Chartier, Chronique de Charles VII roi de France, éd. Vallet de Viriville, t. 1-3, Paris 1858, s. 3, przypis 1; J. Krynen, „Le mort saisit le vif”..., s. 187, 211; tenże, Les légistes idiots politiques. Sur l'hostilité des théologiens à l'égard des juristes, en France, au temps de Charles V, w: Théologie et droit dans la science politique de l'État moderne. Actes de la table ronde organisée par l'École française de Rome avec le concours du CNRS, Rome 12-14 novembre 1987, Rome 1991, s. 189. 
władzę wieczną, wywodzącą się bezpośrednio od Boga albo otrzymywaną poprzez dynastyczne prawo dziedziczenia („Corona non moritur”) ${ }^{33}$. Na płaszczyźnie teorii istniała niezakłócona ciągłość dynastyczna, której nie przerywała śmierć panującego, ponieważ król nigdy nie umiera, ale trwa w swoim następcy. Podobnie trwała jest dynastia, chroniona przez wiecznie trwałą Koronę $e^{34}$. Ta niewidzialna Korona reprezentowała istotę dziedzictwa władzy w późnośredniowiecznej Francji.

Dla współczesnych podstawą pomyślności monarchii było posiadanie pełnoprawnego króla, który był łącznikiem między poddanymi a Bogiem, gwarantem porządku w państwie, osobą zapewniającą królestwu ochronę przed nieszczęściami. Szybkie powołanie i koronacja króla wynikały z obawy przed bezkrólewiem, które prowadziło do walk o tron i zagrażało dobrobytowi królestwa. W opinii powszechnej sakra była konieczna do tego, aby uznać władzę króla za pełnoprawną. Koronacja dawała królowi legitymizację jego rządów. Jan od św. Wiktora uważał, że w powszechnej opinii, dopiero po ceremonii sakry można było nazywać legalnego dziedzica królem, sakra królewska nadawała więc pełnię władzy ${ }^{35}$. Karol V pośpiesznie udał się do Reims, aby tam dokonała się jego koronacja $^{36}$. W XV wieku Karol VII przyjął tytuł króla dziewięć dni po śmierci ojca, ale Joanna d'Arc nazywała go delfinem aż do sakry w Reims. W jej oczach dopiero sakra uczyniła go pełnoprawnym władcą.

Władza nowego monarchy podlegała ograniczeniom tylko w sferze wizualnej, zgodnie z którą „,nowy król pozostaje poza życiem publicznym aż do pogrzebania" poprzedniego władcy i do chwili swojej koronacji ${ }^{37}$. Sakra królewska czyniła władcę, ale nie w sensie sakralnym, gdyż król pozostawał człowiekiem pomimo swojej bliskości z Bogiem, był grzeszny i występny ${ }^{38}$. Konieczność

${ }^{33}$ E.H. Kantorowicz, Dwa ciała króla..., s. 269.

${ }^{34}$ Tamże, s. 268.

${ }^{35}$ Excerpta e Memoriali historiarum, auctore JOHANNE Parisiensi, SANCTI VICTORIS Parisiensis canonico regulari, w: Recueil des Historiens des Gaules et de la France, t. XXI, publié par MM. Guigniaut et de Wailly, compte rendu par L. Delisle, Paris 1855, s. 661.

${ }^{36}$ Chronique des quatre premiers Valois (1327-1393), éd. S. Luce, S.H.F., Paris 1862, s. 144.

${ }^{37}$ Zob. M. Gaude-Ferragu, De la gloire de princes à la corruption des corps. Les funérailles princières à la fin du Moyen Âge dans le royaume de France. Thèse pour le Doctorat sous la dir. de Mme Colette Beaune, Paris 2001, s. 428.

${ }^{38}$ F.-R. Erkens, Vicarius Christi-sacratissimus legislator - sacra majestas. Religiöse Herrschaftslegitimierung im Mittelalter, „Zeitschrift der Savigny Stiftung für Rechtsgeschichte Kanonistische Abteilung", 120, 2003, s. 53. Przegląd badań w kwestii problemu sakralności osoby 
dokonania sakry wynikała z praktykowanego zwyczaju, jaki kierował procedurą następstwa. Sakra powodowała, że król stawał się wybrańcem Boga w oczach ogółu ${ }^{39}$. Karol VII nazywany był delfinem, a dopiero jego sakra dla współczesnych oznaczała, że został wybrany na króla. Mieszczanin paryski nigdy nie nazywał go królem do momentu koronacji w 1429 roku $^{40}$.

W monarchii francuskiej sakrę praktykowano od czasów Karolingów, którzy jako pierwsi odwołali się do biblijnego rytu namaszczenia. Po wyborze króla następowała jego konsekracja, podczas której król otrzymywał błogosławieństwo, po czym składał przysięgę koronacyjną, że będzie strzegł bezpieczeństwa i stał na straży sprawiedliwości. Następnie odbywała się inwestytura - król otrzymywał insygnia swojej władzy: pierścień, miecz, berło, jabłko i włócznię. W dalszej kolejności następowało nałożenie korony na głowę koronowanego oraz intronizacja. Sakra składała się z dwóch elementów: wręczenia insygniów i namaszczenia ${ }^{41}$. Dzięki koronacji panujący stawał się królem uświęconym Bożym namaszczeniem udzielonym przez Kościół, w zamian za obietnice złożone pod przysięgą ${ }^{42}$.

W sferze wizualnej koronacja była manifestacją przezwyciężenia problemów, jakie powodowała śmierć króla. W społeczeństwie, w którym komunikacja opierała się prawie wyłącznie na przekazie ustnym i prawie zwyczajowym, ceremoniał w procesie legitymizacji następstwa tronu odgrywał ważną rolę $e^{43}$. Dziedzicem nie zostawało się w wyniku woli wyrażonej w testamencie zmarłego, ale na mocy prawa publicznego królestwa Francji. Innowacja ta polegała na rozróżnieniu między modelem dziedziczenia per transmissionem, czyli drogą spad$\mathrm{ku}$, opierającym się na prawie cywilnym i prostym lub per remotionem, tj. drogą

króla: tenże, Sakral legitimierte Herrschaft im Wechsel der Zeiten und Räume Versuch eines Überblicks, w: Die Sakralität von Herrschaft, Herrschaftslegitimierung im Wechsel der Zeiten und Räume, Fünfzehn interdisziplinäre Beiträge zu einem weltweiten und epochenübergreifenden Phänomen, hrsg. v. F.-R. Erkens, Berlin 2002, s. 7-32. Zob. także W. Ullmann, Średniowieczne korzenie renesansowego humanizmu, Łódź 1985, s. 76-77.

${ }^{39}$ C. Beaune, Le miroir du pouvoir, Paris 1989, s. 121.

${ }^{40}$ Journal d'un bourgeois de Paris de 1405 à 1449, éd. C. Beaune, Paris 1990, s. 238.

${ }^{41}$ A. Leguai, Fondements et problèmes..., s. 49; R. McKitterick, Królestwa Karolingów. Władza - konflikty - kultura 751-987, tłum. B. Hlebowicz, M. Wilk, Warszawa 2011, s. 225-229.

${ }^{42}$ J. Le Goff, Dtugie średniowiecze, przekł. M. Żurowska, Warszawa 2007, s. 140.

${ }^{43}$ R. Sobotka, Powolywanie władcy w ,Rocznikach” Jana Długosza, Warszawa 2005, passim. Zob. S. Gawlas, Das Erb- und Wahlrecht des Herrschers in Polen im 14. Jahrhundert Das Erbund Wahlrecht des Herrschers in Polen im 14. Jahrhundert, w: Das Goldene Bulle: Politik-Wahrnehmung-Rezeption, hrsg. v. M. Menzel, Berlin 2009, s. 671. 
zaprzeczenia, która dotyczyła rzeczy publicznych, wspólnych dla wszystkich ludzi. Za fizyczną osobą króla istnieje władca legalny posiadający nieśmiertelną godność, która nie wynikała z woli poprzednika ani z treści ceremonii, ale otrzymywało się ją na mocy prawa królestwa ${ }^{44}$. Według religioznawcy G. van der Leeuwa, król jest Bogiem na ziemi. Der Leeuw zwraca jednak uwagę, że istniała świadomość, iż król jest zwykłym człowiekiem, ale nie czczono go jako człowieka, lecz urząd, czyli upostaciowioną moc ${ }^{45}$. Porządek świecki i sakralny uzupełniał się, ponieważ współistniało prawo boskie i ludzkie. Za panowania Karola $\mathrm{V}$ nastąpiło rozdzielenie sfery publicznej i prywatnej, ale nadal obecne było dążenie do ugruntowania w społeczeństwie przekonania, że naturalny i legalny następca tronu jest tym ukochanym, a miłość między królem a poddanymi nie wynika z sakry ani z prawa ${ }^{46}$.

Opinie na temat znaczenia sakry w legitymizacji władzy królewskiej w monarchii francuskiej były rozbieżne. Teoria władzy królewskiej znalazła swoje odzwierciedlenie w tekstach prawniczych i teoretycznych ${ }^{47}$. Z jednej strony utwór Dieudonné de Hongrie, nazywany też Roman de Charles le Chauve wskazywał, że nie można zostać królem dopóki nie otrzyma się sakry w Reims ${ }^{48}$. Utwór ten miał kształtować opinię publiczną w odniesieniu do sakry, służył podkreśleniu mistycyzmu królewskiego w drugiej połowie XIV wieku. Miał charakter apologii monarchii boskiej, która wynikała z potrzeby legitymizacji władzy Walezjuszy ${ }^{49}$. Utwór ten był inspirowany przez ordo z 1365 lub 1364 roku. Bardzo prawdopodobne, że ta „chanson de geste” była inspirowana przez otoczenie Karola V, kiedy przygotowywano jego sakręe ${ }^{50}$. Traité $d u$ sacre, czyli traktat o sakrze królów

${ }^{44} \mathrm{M}$. Valensise, Le sacre du roi: stratégie symbolique et doctrine politique de la monarchie française, „Annales. Économies, Sociétés, Civilisations”, 3, mai-juin 1986, s. 549.

${ }^{45}$ Podaję za J.-P. Roux, Król. Mity i symbole, przeł. K. Marczewska, Warszawa 1998, s. 75.

${ }^{46} \mathrm{~F}$. Autrand, La succession à la couronne de France et les ordonnances de 1374, w: Représentation, pouvoir et royauté à la fin du Moyen Âge. Actes du colloque organisé par l'Université du Maine les 25 et 26 mars 1994, éd. J. Blanchard, Paris 1995, s. 32.

${ }^{47}$ T. Struve, Die Begründung monarchischer Herrschaft in der politischen Theorie des Mittelalters, „Zeitschrift für historische Forschung” 23, 1996, s. 289-323.

${ }^{48}$ D. Collomp, Sacre et royauté dans l'épopée tardive: L'exemple de „Dieudonné de Hongrie”, w: Représentation, pouvoir et royauté..., s. 290; F. Collard, Pouvoirs et culture politique dans la France médiévale, $V^{e}-X V^{e}$ siècle, Paris 1999, s. 179.

${ }^{49}$ D. Collomp, Sacre et royauté..., s. 279-294, tu s. 289. Zob. F. Collard, Pouvoirs et culture..., s. 179 .

${ }^{50}$ D. Collomp, Sacre et royauté..., s. 293. 
francuskich napisany z inspiracji króla przez karmelitę Jeana Goleina, podkreślał nadprzyrodzone cechy króla, które miały swoje uzasadnienie w religii ${ }^{51}$. $\mathrm{W}$ utworze tym podkreślono m.in. zasadę przekazywania tronu w linii męskiej oraz ciągłości, bo Karol V „na wzór swych przodków został koronowany i konsekrowany w Reims" ${ }^{\prime 52}$. Według Goleina, niektórym zbrodniarzom pochwyconym pod Cocherel nie udało się przeszkodzić sakrze Karola V. Nie znajduje to jednak potwierdzenia w przekazach kronikarskich. Można przypuszczać, że zostało to odnotowane, aby wzmocnić szczególne znaczenie sakry królewskiej Karola V ${ }^{53}$. Z drugiej strony, w opinii Evrarta de Trémaugon, autora Le Songe du Vergier, utworu również pisanego na zlecenie króla Karola V, król posiada pełnię władzy (plena potestas) bez oczekiwania na sakrę, ponieważ wynika ona z zasady sukcesji i nie zależy od samego faktu koronacji ${ }^{54}$.

Sakra łączyła w sobie charakter monarszy, boski i społeczny ${ }^{55}$. Wzmacniała i dopełniała władzę królewską, podkreślając jej boski charakter. Z czasem zyskała na przepychu równoważąc te elementy, które utraciła w sferze prawnej ${ }^{56}$. Sakralizacja władzy króla miała mu zapewnić posłuszeństwo poddanych, ich wierne podporządkowanie, a z drugiej strony powodowała groźbę kary boskiej za jego złe postępowanie ${ }^{57}$. Sakra była swego rodzaju konstytucją regulującą stosunki między władcą a społeczeństwem ${ }^{58}$. Król nie miał władzy absolutnej, otrzymywał namaszczenie i insygnia swojej władzy, ale za złamanie prawa musiał

${ }^{51}$ R.A. Jackson, The Traite du sacre of Jean Golein, „Proceedings of the American Philosophical Society”, 113, 1969, s. 305-324; M. Bloch, Królowie cudotwórcy..., s. 387 i n.

${ }^{52}$ M. Bloch, Królowie cudotwórcy..., s. 389.

${ }^{53}$ Tamże, s. 390. Joanna d'Arc uważała Karola VII za króla dopiero od momentu jego koronacji w Reims. Król mógł leczyć skrofuły od otrzymania sakry w 1429 roku.

${ }^{54}$ J. Krynen, „Le mort saisit le vif”..., s. 195.

${ }^{55}$ R.A. Jackson, Le pouvoir monarchique dans la cérémonie du sacre et couronnement des rois de France, w: Représentation, pouvoir et royauté... s. 247.

${ }^{56}$ F. Collard, Pouvoirs et culture..., s. 179. Zob. F.-R. Erkens, Sakral legitimierte..., s. 7-32; tenże, Vicarius Christi..., passim.

${ }^{57}$ J. Le Goff, Kultura średniowiecznej Europy, tłum. H. Szumańska-Grossowa, WarszawaGdańsk 2002, s. 326.

${ }^{58}$ W. Sawicki, Rytuat sakry-koronacji królewskiej jako źródta prawa i ustroju państw średniowiecznej Europy, „Archiwa, Biblioteki i Muzea Kościelne”, 24, 1972, s. 291. Podkreśliła ten fakt U. Borkowska, ,,Regnum i sacerdotium” w pismach Jana Długosza, „Studia Źródłoznawcze”, 26, 1981, s. 9. 
ponieść karę kościelną. Czekała go w takiej sytuacji ekskomunika lub pozbawienie tronu ${ }^{59}$.

W XIV i XV wieku panował we Francji pogląd, że nie ma króla bez sakry. Jak już wspomniano, Joanna d’Arc nie traktowała Karola VII jako króla, ponieważ nie miał on sakry ${ }^{60}$. W późniejszym okresie uważano, że nigdy nie ma wakatu na tronie, ponieważ król jest zawsze mimo braku koronacji, sakry i namaszczenia, pozostając w tzw. uśpieniu ${ }^{61}$. Na przełomie XIV i XV wieku delfin był postrzegany jako ta sama osoba, co jego ojciec i dlatego nie potrzebował przed śmiercią ojca przeprowadzenia swojej sakry i koronacji ${ }^{62}$. Taki pogląd wyznawał miedzy innymi Jean Gerson w 1405 roku. Podobne opinie w późniejszym czasie wyrażał Robert Blonde ${ }^{63}$.

Na przestrzeni średniowiecza zmieniała się rola i znaczenie symboli wła$\mathrm{dzy}^{64}$. Insygnia koronacyjne należały do sfery symbolicznej, będąc nośnikiem ideologii królewskiej ${ }^{65}$. Związane były z nimi określone treści uniwersalne. Insygnia wręczane w czasie obrzędu koronacyjnego współstanowiły o władzy i godności króla; ich użycie przesądzało o prawomocności koronacji; miejsce ich

59 Por. U. Borkowska, , Regnum i sacerdotium”..., s. 9.

${ }^{60}$ R.A. Jackson, ,Vivat rex”. Histoire des sacres et des couronnements en France, 1364-1825, Strasbourg 1984, s. 191.

${ }^{61}$ Motyw uśpionego królu omawiają: R.A. Jackson, „,Vivat rex”..., s. 191; M. Valensise, Le sacre du roi..., s. 548

62 J. Krynen, „Le mort saisit le vif”..., s. 216.

${ }^{63}$ B. Guenée, Un meurtre, une société. L'assasinat du duc d'Orléans 23 novembre 1407, Paris 1992, s. 31-32. Szerzej o kolejności praw do tronu po śmierci Karola VI, zob. tamże, s. 30.

${ }^{64}$ Stan badań nad symbolami władzy przedstawił Z. Piech, Monety, pieczęcie $i$ herby $w$ systemie symboli władzy Jagiellonów, Warszawa 2004, s. 7 i n.

65 Spośród obszernej literatury poświęconej insygniom koronacyjnym, zob. P.E. Schramm, Herrschaftszeichen und Staatssymbolik. Beiträge zu ihrer Geschichte vom 3. bis zum 16. Jahrhundert, 3 Bde., Stuttgart 1954-1956 (Schriften der Monumenta Germaniae Historica); E.F. Twining, A History of the Crown Jewels of Europa, London 1960; tenże, European Regalia, London 1967; W. Maisel, Archeologia prawna Polski, Warszawa-Poznań 1982, s. 218-229; tenże, Archeologia prawna Europy, Warszawa-Poznań 1989, s. 229-256; Z. Piech, Strój, insygnia i atrybuty książt piastowskich do końca XIV wieku, „Kwartalnik Historii Kultury Materialnej”, 38, 1990, s. 3-35, 199-222; M. Rokosz, Polskie insygnia koronacyjne $w$ średniowiecznych fabułach, w: Imagines potestatis..., s. 206-227; Z. Piech, Herrschaftszeichen und Staatssymbolik in der Monarchie der letzten Piasten (1320-1370), ,Quaestiones Medii Aevii Novae”, 1, 1996, s. 43-76; A. Mentzel-Reuters, Die goldene Krone. Entwicklungslinien mittelalterlicher Herrschaftssymbolik, „Deutsches Archiv für Erforschung des Mittelalters", 60, 2004, s. 135-182; Z. Piech, Monety, pieczecie..., passim. O szczególnym, symbolicznym znaczeniu insygniów, R.A. Jackson, Le pouvoir monarchique..., s. 246. Por także o znaczeniu symbolu, J. Le Goff, Kultura średniowiecznej Europy..., s. 394-395. 
przechowywania było związane $\mathrm{z}$ tradycją. Troszczono się o ich zabezpieczenie przed dostaniem się w niepowołane ręce, obawiając się kradzieży. Znaczenie tych oznak władzy królewskiej dalece wykraczało poza postrzeganie ich jako klejnotów monarszych, które król otrzymywał w czasie koronacji. Związane były raczej z ideologią władzy monarszej, uosabiały tradycję i ciągłość monarchii. Wywóz lub kradzież insygniów przed koronacją miały w sposób symboliczny oznaczać brak zgody na przeprowadzenie ceremonii. Powodowały, że uroczystość należało odłożyć, aby wykonać nowe insygnia ${ }^{66}$.

We Francji insygnia koronacyjne, takie jak królewskie szaty i święta ampułka przechowywane były w świątyniach związanych w sposób szczególny z ideologią monarchiczną, czyli w Saint-Rémi i Saint-Denis ${ }^{67}$. We Francji do XIII wieku brak było jednej korony, a w czasie koronacji używano różnych koron ${ }^{68}$. Raymond Cazelles zauważył, że od 1356 roku nastąpiło wzmocnienie pojęcia „korona”, do czego przyczyniała się fizyczna nieobecność Jana Dobrego przebywającego w niewoli angielskiej. Korona symbolizowała trwanie państwa, a król był jedynie jej depozytariuszem ${ }^{69}$. Karol V przywiązywał dużą wagę do insygniów wykorzystywanych w czasie sakry. Wygląd jego korony miał nawiązywać do istniejących już koron królewskich. Obok jabłka królewskiego, wyobrażenia globu, korona była przejawem dążenia władców francuskich do posiadania władzy imperialnej, podobnej do tej, jaką mieli cesarz i papież. Walor symboliczny insygniów królewskich związany był z legendą francuskich dynastii królewskich. Pierwszą troską młodego księcia, przyszłego Karola V, było udanie się w 1356 roku do Luwru, aby obejrzeć insygnia królewskie w skarbcu ojca ${ }^{70}$.

We wszelkiego rodzaju uroczystościach dworskich zarówno o charakterze religijnym, jak i świeckim istotną rolę odgrywało zbiorowe przeżywanie emocji. Ceremonie obejmujące święta rodzinne, dynastyczne, przyjęcia przedstawicieli innych państw były odpowiednio wyreżyserowane, rozbudowane i urządzane

\footnotetext{
${ }^{66}$ M. Rokosz, Polskie insygnia koronacyjne..., s. 208.

${ }^{67}$ RSD, t. 1, s. 29; J. Le Goff, Dlugie średniowiecze..., s. 140.

${ }^{68} \mathrm{~J}$. Barbey, Etre roi. Le roi et son gouvernement..., s. 466, przypis 53.

${ }^{69}$ R. Cazelles, Société politique..., s. 505.

${ }^{70}$ Karol polecił wybrać wyjątkowo cenne kamienie, aby ozdobić nimi jedną z koron, R. Cazelles, Société politique..., s. 506. Spośród prac na temat teorii korony królewskiej w odniesieniu do okresu panowania Karola VI, zob. Ph. Henwood, Administration et vie des collections d'orfèvrerie royales sous le règne de Charles VI (1380-1422), „Bibliothèque de l'École des Chartes”, 138, juillet-décembre 1980, s. 210; A. Coville, La très belle couronne royale au temps des Armagnacs et des Bourguignons, w: Mélanges de N. Iorga, Paris 1933, s. 183-198.
} 
z przepychem. Były one formą komunikacji społecznej, transcendentalnej, sposobem przekazywania określonych sygnałów i oczekiwań ${ }^{71}$. Odwoływano się także do symboliki gestów i kolorów, które podkreślały nadprzyrodzoną władzę kró$\mathrm{la}^{72}$. Święta związane z rodziną królewską były uroczystościami o charakterze publicznym. Członkom rodziny królewskiej organizowano również uroczyste pogrzeby $^{73}$. Opisy niepowodzeń dotykających monarchów kontrastowały z opisami ekstrawagancji i przepychu uroczystości dworskich.

Szczególnego znaczenia w czasie kryzysu następstwa nabierała rozwinięta symbolika obejmowania władzy. Symbol był formą, w której wyrażały się określone treści ideologiczne. „Symbolem uczuć narodowych był monarcha, jego herb i korona. Przywiązanie Francuzów do tak nieudolnych władców jak Jan II Dobry, Karol VI czy później Karol VII, po tym, jak koronował się on w Reims, wskazują, że uczucia dotyczyły symbolu, a nie osoby. Symbolu państwa i narodu, skoro paryska koronacja Henryka VI nie miała skutków równych skutkom koronacji w Reims" ${ }^{74}$.

Koronacje w średniowiecznych monarchiach europejskich przebiegały według ściśle określonych zasad. Obejmowały szereg czynności, które były uregulowane w tzw. ordines coronandi, jak i utrwalone w powszechnej świadomości społecznej w wyniku tradycji i doświadczenia historycznego. Owe „porządki koronowania" ulegały zmianom w czasie i przestrzeni, stanowiąc jedno z podstawowych źródeł pozwalających zrekonstruować przebieg ceremonii. Ordines coronandi były silnie osadzone w liturgii kościelnej, co wiązało się zarówno z przekonaniem o sakralnym charakterze władzy królewskiej, jak i z próbą poddania jej kontroli przez Kościół. Na przebieg koronacji wpływ miały także czynniki pozaliturgiczne, które dopełniały właściwe uroczystości, jak „odnalezienie króla w tłumie", ubranie go w szaty koronacyjne, wybór miejsca koronacji, dobór jej uczestników oraz ukazanie się ludowi ukoronowanego władcy (wjazd do miasta,

\footnotetext{
${ }^{71}$ A. Dąbrówka, Średniowiecze. Korzenie, Warszawa 2005, s. 81 i n.

${ }^{72}$ Spośród licznych opracowań poświęconych problemowi symbolicznego myślenia średniowiecznego człowieka zob. m.in. J. Le Goff, Człowiek średniowiecza, w: Człowiek średniowie$c z a$, red. tenże, tłum. M. Radożycka-Paoletti, Warszawa-Gdańsk 1996, s. 45-46; M. Pastoureau, Średniowieczna gra symboli, tłum. H. Igalson-Tygielska, Warszawa 2006; J-Cl. Schmitt, Gest w średniowiecznej Europie, tłum. H. Zaremska, Warszawa 2006.

${ }^{73}$ Przykładem może być pogrzeb Joanny d'Evreux, trzeciej żony Karola IV Pięknego, Chronique des règnes de Jean II et de Charles V..., t. 2: 1364-1380, s. 151-152.

${ }^{74}$ B. Zientara, Świt narodów europejskich. Powstawanie świadomości narodowej na obszarze Europy pokarolińskiej, Warszawa 1985, s. 333-334.
} 
hołd mieszczan oraz uczta królewska na zamku). Poznanie pozaliturgicznych elementów związanych z koronacją władcy możliwe jest dzięki źródłom narracyjnym i źródłom ikonograficznym. Warto jednocześnie zauważyć, że tzw. porządki koronacji zawierały idealny przebieg ceremonii, który z różnych względów nie zawsze był w pełni możliwy do przeprowadzenia. Weryfikacja zapisów ordines na podstawie informacji zawartych w pozostałych źródłach epoki umożliwia uzyskanie odpowiedzi na pytanie o przebieg uroczystości, jak i wyobrażenie o niej w ówczesnym społeczeństwie. Uwaga ta odnosi się przede wszystkim do źródeł narracyjnych, które ze względu na swoją tendencję jedne kwestie uwypuklały, a inne pomijały milczeniem ${ }^{75}$.

W tradycji monarchii francuskiej proces inauguracji władzy królewskiej rozpoczynał się w momencie śmierci króla. Pierwszą podejmowaną wówczas czynnością było ustalenie miejsca pobytu jego następcy. Sposób przywołania przyszłego władcy mógł przybierać różne formy, z których jedną było przebudzenie. Na tym etapie najważniejszą rolę odgrywali przedstawiciele elit królestwa, którzy symbolicznie reprezentowali całą społeczność kraju oczekująca na przerwanie wakatu na tronie i ustanowienie nowego władcy. Do królewskich komnat udawali się biskupi Laon, Beauvais i Langres oraz dwunastu parów królestwa. W dalszej kolejności następowała rozmowa z królewskim szambelanem, podczas której przedstawiciele ludu domagali się przywołania następcy tronu. Kiedy ten odpowiadał, że śpi, przybyli domagali się jego zbudzenia, bo nadszedł dzień jego sakry. Biskupi otaczali łoże króla i pomagali śpiącemu się podnieść. Według R.A. Jacksona scena budzenia króla odbywała się według analogicznego schematu przez blisko trzy stulecia, pomimo tego, iż formuła sakry mogła przybierać różne warianty ${ }^{76}$. Motyw ten przedstawiały również sceny koronacji królów francuskich w XIV wieku utrwalone na miniaturach kodeksów ufundowanych przez

${ }^{75} \mathrm{Z}$ najważniejszych prac dotyczących średniowiecznych łacińskich ordines coronandi, zob. P.E. Schramm, Geschichte des englischen Königtums im Lichte der Krönung, Weimar 1937; tenże, Herrschaftszeichen und Staatssymbolik. Beiträge zu ihrer Geschichte vom 3. bis zum 16. Jahrhundert, t. 1-3, Stuttgart 1954-1956 (Schriften der Monumenta Germaniae Historica); tenże, Der König von Frankreich: das Wesen der Monarchie vom 9. bis zum 16. Jahrhundert. Ein Kapitel aus der Geschichte des abendländischen Staates, t. 1-2, Weimar 1939, 2. Auf., Darmstadt 1960; J.L. Nelson, Inaugration Rituals, w: tejże, Politics and Ritual in Early Medieval Europe, London 1986, s. 283-307.

${ }^{76}$ Y.-M. Bercé, Le roi caché. Sauveurs et imposteurs..., s. 255; R.A. Jackson, „Vivat rex”..., rozdz. IX: Le roi dormant, s. 123-144. Na temat motywu „śpiącego króla”, A. Boureau, Ritualité politique et modernité monarchique. Les usages de l'héritage médiéval, w: L'État ou le roi..., s. 21 in. 
Karola V. Pierwsza z nich, zamieszczona w Le livre du sacre de Charles V, prezentowała wspomnianego władcę przed ceremonią ukoronowania. Król „siedział na łożu, otoczony przez biskupów, którzy przybyli go obudzić" ${ }^{77}$.

Jednym z warunków, które decydowało o ważności koronacji, było przeprowadzenie jej w odpowiednim miejscu ${ }^{78}$. We Francji, ostatecznie za panowania władców z dynastii Kapetyngów, ukształtował się zwyczaj przeprowadzania koronacji królewskich w Reims. Znane są jednak przykłady, kiedy ceremonia ta odbyła się w innych miejscach. Ludwik IV koronował się w Laon, Hugo Kapet w Noyon, a następnie, prawdopodobnie po raz drugi, w Reims. Z kolei Robert Pobożny i Ludwik VI Gruby sakrę królewską otrzymali w Orleanie. Po raz pierwszy w Reims koronował się Ludwik Pobożny w 816 roku. Ważną rolę w tym mieście, obok katedry w Reims, gdzie odbywała się ceremonia, odgrywało także sanktuarium Saint-Rémi, gdzie przechowywano Świętą Ampułkę z krzyżmem. Jak powszechnie wierzono, miało ono zostać zesłane przez Boga na chrzest Chlodwiga, o czym mówi legenda powstała w IX-XI wieku. Z tego powodu arcybiskupi Reims rościli sobie wyłączne prawo do koronacji królów francuskich. Święty olej służył do ich namaszczania i dopełniał sakry. Zachowane informacje wskazują, że w okresie rządów Kapetyngów, jedynie w przypadku koronacji Ludwika VI ten element ceremonii został pominięty ${ }^{79}$. O ważności koronacji przesądzał także fakt, że została ona dokonana przez upoważnioną do tego osobę. We Francji był nią arcybiskup Reims. „Prawo nadawania królom sakry związane było z osobą

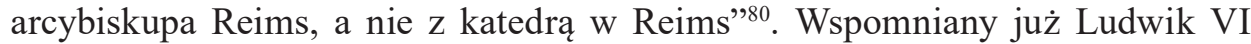
Gruby, jako jedyny z dynastii Kapetyngów, został w 1108 roku koronowany przez arcybiskupa Sens ${ }^{81}$.

Karol V poprzez koronację uprawomocniał swoje rządy, a także potwierdzał charyzmę, w którą przed sakrą powątpiewała Krystyna de Pizan ${ }^{82}$. Władca ten rozpoczął swoje panowanie na wieść o śmierci ojca, z tego powodu dokonano

77 Y.-M. Bercé, Le roi caché. Sauveurs et imposteurs..., s. 255.

${ }^{78}$ Z. Dalewski, Władza, przestrzeń, ceremoniat. Miejsce i uroczystość inauguracji władzy w Polsce średniowiecznej do końca XIV w., Warszawa 1996, s. 207.

${ }^{79}$ J. Le Goff, Dlugie średniowiecze..., s. 140.

${ }^{80}$ A. Bonnefin, Sacre des rois de France..., s. 169.

${ }^{81}$ E.M. Hallam, J. Everard, Francja w czasach Kapetyngów 987-1328, tłum. U. Kowalczyk, Warszawa 2006, s. 95, 341.

${ }^{82}$ R. Cazelles, Société politique..., s. 465. 
jego szybkiej koronacji ${ }^{83}$. Karol V Mądry był koronowany 19 maja 1364 roku przez arcybiskupa Jana de Craon. Ceremonia przebiegła według zwyczaju i bez elementów innowacji ${ }^{84}$. Ważnym źródłem do poznania przebiegu tej uroczystości jest Livre du sacre, która została wykonana na polecenie nowego władcy w rok później. Była to pełna przepychu księga z tekstem w języku łacińskim i francuskim. Jednym z głównych założeń Karola V było, aby w sposób głęboko przemyślany przedstawić we wspomnianym kodeksie relacje między królem a duchownymi i świeckimi dostojnikami królestwa. Władca pragnął, dzięki ideowej wymowie manuskryptu, legitymizować w elitach monarchii swoją władzę i zapewnić sobie oparcie dla rządów otrzymanych w akcie koronacji dokonanym w wyniku powszechnego konsensusu. Stąd w opisie ceremoniału koronacyjnego w Livre du sacre znalazła się scena uroczystej aklamacji i hołdu złożonego nowemu władcy przez poddanych bezpośrednio po akcie koronacji. Król siedzi lub stoi wówczas w otoczeniu biskupów i książąt, którzy swoimi rękami sięgają, aby dotknąć korony królewskiej.

W jednym z rękopisów Live du sacre przedstawiono, jak Karol V po akcie kościelnego namaszczenia, już z koroną na głowie, trzymając berło w prawej, a rękę sprawiedliwości w lewej ręce, wstępuje na swego rodzaju scenę osadzoną na czterech filarach. Podczas namaszczenia i koronacji zajmował miejsce na tronie przed ołtarzem w chórze. Jako berło dzierżył podczas tego etapu ceremonii i kolejnych, nie zwykłe berło, ale insygnium wykonane na swoje specjalne polecenie, i - co bardzo podkreślono na ilustracji - berło Karola Wielkiego, bowiem Walezjusze, a zwłaszcza Karol V, przypisywali temu władcy szczególne znaczenie. Chociaż, aby historycznie uzasadnić zwyczaj namaszczenia królewskiego, na dworze francuskim odwoływano się do Chlodwiga, to jednak legitymizacja panowania Karola V wymagała odniesienia do cesarza frankijskiego, Karola Wielkiego.

W dalszym etapie koronacji arcybiskup Reims i duchowni oraz świeccy panowie królestwa prowadzili króla na scenę, na której stał tron (ten sam lub podobny jak w akcie koronacji). Z zamieszczonego pod ilustracją komentarza można

${ }^{83}$ Chronique des quatre premiers Valois..., s. 144; 148-149.

${ }^{84}$ Tamże, s. 148-149; R. Cazelles, Société politique..., s. 463 i n.; A.D. Hedeman, Copies in context. The coronation of Charles $V$ in his Grandes Chroniques de France, w: Coronations..., s. 72-84. Sporządzona na polecenie Karola V księga Livre du sacre posłużyła do koronacji Karola VI (R. Cazelles, Société politique..., s. 464, przypis 47; The Coronation Book of Charles V of France [Cottonian Ms. Tiberius B. VIII], ed. E.S. Dewick, Henry Bradshaw Society, vol. 16, London 1899). 
wyczytać, że we wcześniejszym okresie królowi towarzyszyło dwunastu panów, jednak w 1364 roku było ich siedmiu. Czterech z nich można zidentyfikować na podstawie znaków heraldycznych. Byli to: arcybiskup Reims i biskup Beauvais oraz książęta Anjou i Burgundii. W dwóch następujących po sobie kolejno scenach rozgrywały się najważniejsze wydarzenia ceremonii. Arcybiskup Reims wypowiadał formułę, dzięki której potwierdzany był status królewski dopiero co koronowanego (status regis). Livre du sacre nie pozostawiała żadnych wątpliwości, że tron przechodzi z ojca na syna, w ojcowskim dziedzictwie (paterna successio) i według prawa dziedziczenia (hereditarium ius). Jest to najważniejsze przesłanie całego aktu koronacji. Wszyscy duchowni i świeccy dostojnicy oraz ich ceremonialne działania służyły temu, aby zaświadczyć o sakralności monarchii dziedzicznej. W końcu duchowni i świeccy szli w procesji. W symbolicznym akcie podnosili swoje prawe dłonie, jak przy przysiędze, dotykając korony na królewskiej głowie. To ceremonialne dotykanie korony przez panów królestwa miało znaczenie podobne, jak rytualna aklamacja namaszczonego i koronowanego już króla. Arcybiskup Reims po zakończonym namaszczeniu i usadowieniu się króla na tronie składał mu pocałunek pokoju, mówiąc zgodnie z tradycją koronacji królewskich: „Vivat rex in eternum”. Nowością uroczystości w 1364 roku było odwołanie do wieczności, w którym wyrażało się istotne dla całej ceremonii transpersonalne wyobrażenie o panowaniu królewskim. Jednak w Livre du sacre zamieszczono teologicznie uzasadnienie odwołania do wieczności wyłącznie dla arcybiskupa Reims jako najwyższego rangą duchownego podczas ceremonii koronacyjnej. Następnie miała miejsce aklamacja przez lud, ograniczająca się do prostego okrzyku „Vivat rex”. Tego rodzaju zwyczaj stosowany był również w czasach wcześniejszych ${ }^{85}$.

Karol VI po opuszczeniu Melun udał się 25 października 1380 r., w uroczystym pochodzie na sakrę do Reims. Jego wjazd do miasta został opóźniony z powodu nieobecności regenta, który musiał zawrócić do Melun. Przyszły król wkroczył do Reims przy dźwiękach głośnej muzyki. Towarzyszyli mu jego wujowie, książęta krwi, hrabiowie i możni. Następnego dnia następca tronu udał się do udekorowanego z przepychem kościoła ${ }^{86}$. Jego koronacja odbyła się 4 listopada

${ }^{85}$ M. Kintzinger, „Coronam sustentare”. Krönung und Konsens in Frankreich und im deutschen Reich im Spätmittelalter, w: Ritualisierung politischer Willensbildung. Polen und Deutschland im hohen und späten Mittelalter, hrsg. v. W. Fałkowski, B. Schneidmüller, S. Weinfurter, Wiesbaden 2010, s. 47-63.

${ }^{86}$ L.-P. Todière, Charles VI, les Armagnacs et les Bourguignons, Tours 1848, s. 6. 
1380 roku, po upływie półtora miesiąca od śmierci ojca ${ }^{87}$. Uroczystość została przeprowadzona z zachowaniem przewidzianego przez tradycję porządku. Michel Pintoin podkreślił autentyczność ksiąg, pochodzących z Saint-Denis, które służyły do koronacji królów francuskich ${ }^{88}$. Karol VI otrzymał sakrę i koronę w Reims, w obecności wujów, konetabla Oliviera de Clisson i dużej liczby możnych $^{89}$. Oprócz arcybiskupa Rouen w ceremonii koronacyjnej asystowali tylko dwaj biskupi z opactwa z Saint-Denis. Podczas ceremonii ubrany był w strój królewski, a na głowie miał diadem. Został koronowany przy pomocy Świętej Ampułki przez arcybiskupa Reims, w otoczeniu kleru. Potem został pasowany na rycerza przez księcia Anjou. Koronacja Karola VI na króla odbyła się w chapelle $d u$ Palais $^{90}$. W koronacji uczestniczyła również królowa, która otrzymała święte namaszczenie, oraz rodzina królewska. Autor Chronique des quatre premiers Valois podkreślił, że była to uroczystość z udziałem „najważniejszych w królestwie i najznamienitszych książąt, braci króla, możnych i baronów Francji”’1. Uroczystość zakończyła się spektaklem na cześć władcy ${ }^{92}$. Po jej zakończeniu trwały zabawy i turnieje, w których uczestniczył sam król ${ }^{93}$. Po koronacji książęta zabrali Karola VI do Paryża. Na spotkanie królewskiemu orszakowi wyszli mieszczanie ubrani w biało-zielone stroje ${ }^{94}$. Król wkroczył do Paryża ubrany w najlepszy, bogato zdobiony strój, szaty pokryte kwiatami lilii, czyli symbol władców Francji. Do stolicy koronowany już władca udał się w towarzystwie swoich wujów ${ }^{95}$,

${ }^{87}$ Chronique des règnes de Jean II et de Charles V..., t. 3, s. 1; Chronique des quatre premiers Valois..., s. 290-291; RSD, t. 1, s. 29.

${ }^{88}$ RSD, t. 1, s. 615.

${ }^{89}$ Chronique de règnes de Jean II et de Charles V..., t. 3, s. 1.

${ }^{90}$ RSD, t. 1, s. 615.

${ }^{91}$ Chronique des quatre premiers Valois..., s. 291.

${ }^{92}$ L.-Cl. Douët-d'Arcq, Choix de pièces inédites relatives au règne de Charles VI, t. 1, Paris 1863, s. $1-4$.

${ }^{93}$ RSD, t. 1, s. 615. Niektórzy takie zachowanie króla oceniali negatywnie, że nie przystoi ono królowi.

${ }^{94}$ Podaję za: L.-P. Todière, Charles VI..., s. 6.

${ }^{95}$ Chronique des quatre premiers Valois..., s. 291. 
gdzie odbyło się radosne i uroczyste przyjęcie nowego monarchy ${ }^{96}$, a także turnieje rycerskie, w których sam również wziął udział ${ }^{97}$.

Karol VII koronował się w 1422 roku w Poitiers, ale nie otrzymał wtedy namaszczenia. Na króla Francji został wybrany przez aklamację w Méhun-sur-Yvrès, na południe od Paryża. Podniesiono wówczas w górę królewską chorągiew, a pretendenta do korony pozdrowiono okrzykiem „Vive le Roy” („le roi est mort!, vive le roi" $)^{98}$. Dopiero w kilka lat później, w lipcu 1429 roku, Karol VII koronował się ostatecznie w Reims w obecności Joanny d'Arc. Przeszkodą do dokonania sakry w tym miejscu bezpośrednio po śmierci Karola VI był fakt, że pozostawało ono w rękach Anglików. Świadomi tego byli doradcy króla: La Trémoille i arcybiskup Renard de Chartres. Karol VII chciał przygotować swój uroczysty wjazd do Reims, dlatego 3 lipca skierował list do mieszkańców miasta. Mieli oni wysłać do niego delegację, która miałaby przygotować jego wjazd. Rada miejska miała jednak problem z podjęciem decyzji. Swoją delegację wysłali do niej także Anglicy. W poselstwie angielskim znalazł się biskup Beauvais, Pierre Cauchon, którego zwierzchnikiem był arcybiskup Reims, Renaud de Chartres. Aimé Bonnefin podkreśliła, że Pierre Cauchon odgrywał podwójną rolę. Był w delegacji angielskiej i przypomniał mieszkańcom miasta o tym, że złożyli oni przysięgę wierności Henrykowi VI. Z kolei brat Richard, przed wkroczeniem wojsk Karola VII i Joanny d'Arc, skutecznie obudził sentyment lojalności u niższego kleru i ludu do rodzimego władcy. Mieszczaństwo pozostawało po stronie Anglików. Karol VII wkroczył do Reims 16 lipca 1422 roku, a jego sakra odbyła się następnego dnia ${ }^{99}$.

W czasie koronacji Karola VII wydarzeniem symbolicznym było zajęcie w katedrze miejsca po prawej stronie króla przez Joannę d’Arc. Było to miejsce honorowe, które z reguły przypadało osobie z najbliższej rodziny króla. Jednak Karol Orleański był wtedy uwięziony w Anglii, a książę d’Angoulême nie przybył na uroczystość. Po zakończeniu sakry król dotykał skrofułów, co miało rozwiać wątpliwości, czy jest prawowitym królem i legalnym synem Karola VI. Jak wiadomo - władca legalny miał zdolność i moc leczenia skrofułów. Wieczorem

\footnotetext{
${ }^{96}$ Informacje na temat wjazdu Karola VI po jego koronacji do Paryża zawiera także Les Grandes Chroniques de France, Chronique des règnes de Jean II et Charles V, t. 3, Paris 1920, s. 1.

${ }^{97}$ RSD, t. 1, s. 615.

${ }^{98}$ Z. Dalewski, Władza, przestrzeń, ceremoniat..., s. 207; R.E. Giesey, The Royal Funeral Ceremony in Renaisance France, Travaux d'humanisme et de renaissance 37, Genève 1960, s. 134.

${ }^{99}$ A. Bonnefin, Sacre des rois de France..., s. 170.
} 
Karol VII zjadł kolację z urzędnikami miejskimi. Jego sakra została opisana precyzyjnie i szczegółowo. Miała duże znaczenie dla świadomości narodowej Francuzów, będąc nie tylko manifestacją patriotyzmu. Mimo, iż Karol VII był już królem, chodziło nie tylko o zamanifestowanie potęgi władzy królewskiej osłabionej panowaniem Karola VI i problemami związanymi z wojną stuletnią, ale również o przestrzeganie obyczaju, zgodnie z którym król musiał być koronowany w Reims. W kontekście przytoczonych informacji należy zwrócić uwagę, że w powszechnym odczuciu społecznym najważniejsze znaczenie miało namaszczenie. Sama koronacja nie była wystarczająca ${ }^{100}$.

W uroczystościach koronacyjnych istniała pewna powtarzalność. Podkreślić należy widoczność zachowanej tradycji. Wraz z koronacją władcy następowało za każdym razem odnowienie czasu monarchicznego, jego odrodzenie. Ceremonia koronacji nowego króla była formą wizualizacji jego władzy. W XIV i XV wieku wzrósł w niej udział społeczeństwa. Ważną rolę pełniła publiczność: otoczenie władcy i lud przybyły na uroczystośćc ${ }^{101}$. Powołanie nowego władcy oznaczało przezwyciężenie kryzysu spowodowanego śmiercią jego poprzednika. Szczególną rolę odgrywało manifestowanie oznak władzy królewskiej. Podczas ceremonii stosowano także odpowiednie symbole i stroje. Karol V polecił odtworzyć przebieg swojej koronacji. Bogato iluminowany manuskrypt Le livre du sacre de Charles $V$, odzwierciedlający przepych królewskiej sakry, powstał na zamówienie Karola V, w 1365 roku, a więc w rok po koronacji, i znalazł się następnie w królewskiej bibliotece. Opisana tam intronizacja władców francuskich zawierała ważne elementy, które zostały zaczerpnięte ze znanych ordines coronandi $i^{102}$.

Po uroczystej sakrze i koronacji, odbywał się wjazd króla do stolicy. Służył on manifestacji ciągłości władzy królewskiej, uświetnieniu dynastii i władzy nowego króla. W XIV i XV wieku, obok istniejących symboli zwierzchniej władzy królewskiej, obserwujemy rozbudowany system manifestacji władzy w postaci wjazdów królewskich do miast, nie tylko do stolicy. We Francji uzyskaną w wyniku koronacji władzę królewską legitymizowano poprzez wjazd do Paryża. Pojawienie się w tym mieście nowo ukoronowanego władcy i jego małżonki było stałym elementem koronacji. W źródłach można odnaleźć liczne przykłady

100 Tamże, s. 171.

${ }^{101}$ Por. zbiór studiów Investitur- und Krönungsrituale. Herrschaftseinsetzungen im kulturellen Vergleich, hrsg. v. M. Steinicke, S. Weinfurter, Köln-Weimar-Wien 2005.

102 Zob. Chronique des règnes de Jean II et de Charles V..., t. 2, s. 1-2. 
takich wjazdów. Filip V Długi po koronacji udał się do Paryża, gdzie został uroczyście przyjęty przez poddanych ${ }^{103}$. W analogiczny sposób postąpił Jan II, który po koronacji wjechał do Paryża, gdzie świętowano cały tydzieńn ${ }^{104}$. Karol V po swojej koronacji udał się do paryskiej katedry Notre-Dame, a potem do pałacu królewskiego ${ }^{105}$. Odbyło się tam następnie uroczyste przyjęcie dla dostojników. Przez dwa kolejne dni odbywały się turnieje, w których brali udział m.in. król Cypru, a także hrabiowie i baronowie Królestwa ${ }^{106}$. Podczas królewskich wjazdów dużą aktywność wykazywali przedstawiciele poszczególnych stanów społecznych, którzy w procesjonalnym pochodzie wychodzili na spotkanie z nowym monarchą ${ }^{107}$.

Koronację jako ryt i widowisko cechowała powtarzalność. Cykliczność dotyczyła procedur i gestów niezbędnych do legitymizacji władzy nowego monarchy. Podstawową rolę odgrywało tutaj królewskie otoczenie, które dokładało starań, aby jak najszybciej doprowadzić do ukoronowania elekta. Istniało przekonanie o ciągłości władzy i konieczności skrócenia okresu bezkrólewia, tzw. vacu$u m^{108}$. Przyczyną wzrostu roli środowisk dworskich był m.in. okres niepewności powstający w sytuacji braku na tronie prawowitego następcy. Zgodnie z tradycją powinien on pochodzić z królewskiego rodu, a dziedziczenie władzy powinno odbywać się z ojca na syna.

Przebieg uroczystości koronacyjnych przekazywany jest przez kronikarzy w sposób schematyczny. Wszystko miało dziać się według ustalonego porządku, którego przestrzeganiem zajmowały się osoby należące do środowiska dworskiego, będące zarazem uczestnikami ceremonii. Zaliczymy do nich duchownych, możnych, książęta, członków królewskiej rodziny. W sferze prawnej, podstawą zapewnienia ciągłości władzy było posiadanie legalnego następcy (syna lub sukcesora wybranego przez osoby do tego wyznaczone). Za pomocą różnego rodzaju

${ }^{103}$ Excerpta e Memoriali historiarum..., s. 665; H. Scheidgen, Die französische Thronfolge (987-1500). Der Ausschluß der Frauen und das salische Gesetz, Bonn 1976, s. 127.

${ }^{104}$ Chronique des règnes de Jean II et de Charles V..., t. 1, s. 27.

105 Żona Karola V podążyła bezpośrednio do pałacu, nie biorąc udziału we mszy, Chronique des règnes de Jean II et de Charles V..., t. 2, s. 2.

${ }^{106}$ Chronique des règnes de Jean II et de Charles V..., t. 2, s. 4.

${ }^{107}$ E. Petit, Entrée du roi Charles VI à Dijon sous Philippe-le-Hardi, fêtes et réjouissances en Bourgogne, février 1390, Dijon 1885.

${ }^{108}$ A. Gieysztor, „Ornamenta regia” w Polsce XV wieku, w: Sztuka i ideologia XV wieku, red. P. Skubiszewski, Warszawa 1978, s. 157. 
symboliki zastosowanej w czasie pogrzebu i koronacji dążono do podkreślania ciągłości władzy w sferze sakralnej i publicznej. Miała ona oddziaływać na opinię publiczną. $Z$ obawy, że to, co niewidoczne, nie ma znaczącej siły oddziaływania, czy wręcz uznawane jest za nieistniejące, konieczne było kształtowanie opinii publicznej poprzez manifestowanie tego, co do tej pory było ukryte.

\section{Bibliografia}

\section{Źródła}

Chartier J., Chronique de Charles VII roi de France, éd. Vallet de Viriville, t. 1-3, Paris 1858.

Chronique des quatre premiers Valois (1327-1393), éd. S. Luce, S.H.F., Paris 1862.

Chronique des règnes de Jean II et de Charles V, éd. R. Delachenal, t. 1-4, Paris 19101920.

Chronique du Religieux de Saint-Denys contenant le règne de Charles VI de 1380 à 1422, publiée en latin et traduite par M. L. Bellaguet, vol. 1-6, Paris 1839-1852; reproduite avec une introduction de Bernard Guenée en trois tomes contenant chacun deux volumes, Paris 1994.

Chronique latine de Guillaume de Nangis de 1113 à 1300, avec les continuations de cette chronique de 1300 à 1368, éd. H. Géraud, t. 2, Paris 1863.

Chronique normande du XIV siècle, éd. A., E. Molinier, S.H.F., Paris 1882.

Excerpta e Memoriali historiarum, auctore JOHANNE Parisiensi, SANCTI VICTORIS Parisiensis canonico regulari, w: Recueil des Historiens des Gaules et de la France, t. XXI, publié par MM. Guigniaut et de Wailly, compte rendu par L. Delisle, Paris 1855, s. 630-676.

Journal d'un Bourgeois de Paris de 1405 à 1449, éd. C. Beaune, Paris 1990.

Les Grandes Chroniques de France, Chronique des règnes de Jean II et Charles V, t. 3, Paris 1920.

The Coronation Book of Charles V of France (Cottonian Ms. Tiberius B. VIII), ed. E.S. Dewick, Henry Bradshaw Society, vol. 16, London 1899.

\section{Opracowania}

Autrand F., La succession à la couronne de France et les ordonnances de 1374, w: Représentation, pouvoir et royauté à la fin du Moyen Âge. Actes du colloque organisé par l’Université du Maine les 25 et 26 mars 1994, éd. J. Blanchard, Paris 1995, s. 25-32.

Bak J.M., Introduction. Coronation studies - past, present, and future, w: Coronations. Medieval and Early Modern Ritual, ed. J.M. Bak, Berkley-Los Angeles-Oxford 1990, s. 1-10.

Balandier G., Le pouvoir sur scènes, Paris 1980. 
Barbey J., Etre roi. Le roi et son gouvernement en France de Clovis à Louis XVI, Paris 1992.

Bercé Y.-M., Le roi caché. Sauveurs et imposteurs. Mythes politiques populaires dans l'Europe moderne, Paris 1990.

Beaune C., Le miroir du pouvoir. Introduction Avril Françoise, avec la collaboration du Départament des Manuscrits de la Bibliothèque Nationale, collection Banque Nationale de Paris, Paris 1989.

Bloch M., Królowie cudotwórcy. Studium na temat nadprzyrodzonego charakteru przypisywanego władzy królewskiej zwłaszcza we Francji $i$ w Anglii, tłum. J.M. Kłoczowski, Warszawa 1998.

Bloch M., La France sous les derniers Capétiens 1223-1328, Paris 1958.

Bonnefin A., Sacre des rois de France, Limoges 1982.

Borkowska U., Codzienny i odświętny ceremoniat religijny na dworze Jagiellonów, w: „Theatrum ceremoniale” na dworze książat i królów polskich. Materiały z konferencji naukowej zorganizowanej przez Zamek Królewski na Wawelu i Instytut Historii Uniwersytetu Jagiellońskiego w dniach 23-25 marca 1998, red. M. Markiewicz, R. Skowron, Kraków 1999, s. 61-85.

Borkowska U., Królewskie zaślubiny, narodziny i chrzest, w: „,Imagines potestatis”. Rytuaty, symbole i konteksty fabularne władzy zwierzchniej w Polsce X-XV w. (z przykładem czeskim i ruskim), red. J. Banaszkiewicz, Warszawa 1994, s. 75-92.

Borkowska U., „Regnum” i „,sacerdotium” w pismach Jana Dtugosza, „Studia Źródłoznawcze", 26, 1981, s. 3-21.

Boureau A., Ritualité politique et modernité monarchique. Les usages de l'héritage médiéval, w: L'État ou le roi. Les fondations de la modernité monarchique en France (XIVe-XVII siècles), éd. N. Bulst, R. Descimon, A. Guerreau, Paris 1996, s. 9-25. Table ronde du 25 mai 1991 organisée par N. Bulst et R. Descimon à l'École Normale Supérieure.

Bryant L.M., La cérémonie de l'entrée à Paris au Moyen Âge, „Annales. Économies, Sociétés, Civilisations", 3, mai-juin 1986, s. 513-542.

Bryant L.M., The King and the City in the Parisian Royal Entry Ceremony: politics, ritual, and art in the Renaissance, Genève 1986.

Bryant L.M., The medieval entry ceremony at Paris, w: Coronations. Medieval and Early Modern Ritual, red. J.M. Bak, Berkley-Los Angeles-Oxford 1990, s. 88-113.

Cazelles R., Société politique, noblesse et couronne sous Jean le Bon et Charles V, Genève-Paris 1982.

Chartrou J., Les entrées solennelles et triomphales à la Renaissance (1484-1551), Paris 1928.

Delachenal R., Histoire de Charles V, t. 1-5, Paris 1909-1931.

Collard F., Pouvoirs et culture politique dans la France médiévale, $V^{e}-X V^{e}$ siècle, Paris 1999. 
Collomp D., Sacre et royauté dans l'épopée tardive: L'exemple de „Dieudonné de Hongrie”, w: Représentation, pouvoir et royauté à la fin du Moyen Âge. Actes du colloque organisé par l'Université du Maine les 25 et 26 mars 1994, éd. J. Blanchard, Paris 1995, s. 279-294.

Coville A., La très belle couronne royale au temps des Armagnacs et des Bourguignons, w: Mélanges de N. Iorga, Paris 1933, s. 183-198.

Cuvillier J.-P., Corona, III. Frankreich, w: Lexikon des Mittelalters, 3, 1995, szp. 253255.

Dalewski Z., Władza, przestrzeń, ceremoniał. Miejsce i uroczystość inauguracji władzy w Polsce średniowiecznej do końca XIV w., Warszawa 1996.

Douët-d'Arcq L.-Cl., Choix de pièces inédites relatives au règne de Charles VI, t. 1, Paris 1863.

Erkens F.-R., Sakral legitimierte Herrschaft im Wechsel der Zeiten und Räume Versuch eines Überblicks, w: Die Sakralität von Herrschaft, Herrschaftslegitimierung im Wechsel der Zeiten und Räume, Fünfzehn interdisziplinäre Beiträge zu einem weltweiten und epochenübergreifenden Phänomen, hrsg. v. F.-R. Erkens, Berlin 2002, s. 7-32.

Erkens F.-R., Vicarius Christi - sacratissimus legislator - sacra majestas. Religiöse Herrschaftslegitimierung im Mittelalter, „Zeitschrift der Savigny Stiftung für Rechtsgeschichte Kanonistische Abteilung", 120, 2003, s. 1-55.

Fouquet G., Seggern von H., G. Zeilinger, Höfische Feste im Spätmittelalter. Eine Einleitung, w: Höfische Feste im Spätmittelalter, hrsg. v. G. Fouquet, H. von Seggern, G. Zeilinger, Kiel 2003 (Mitteilungen der Residenzen-Kommission der Akademie der Wissenschaften zu Göttingen, Sonderheft 6), s. 9-18.

Gawlas S., Das Erb- und Wahlrecht des Herrschers in Polen im 14. Jahrhundert Das Erbund Wahlrecht des Herrschers in Polen im 14. Jahrhundert, w: Das Goldene Bulle: Politik-Wahrnehmung-Rezeption, hrsg. v. M. Menzel, Berlin 2009, s. 665-712.

Gaude-Ferragu M., De le gloire des princes à la corruption des corps. Les funérailles princières à la fin du Moyen Âge dans le royaume de France. Thèse pour le Doctorat sous la dir. de Mme Colette Beaune, Paris 2001.

Giesey R.E., The Royal Funeral Ceremony in Renaisance France, Travaux d'humanisme et de renaissance 37, Genève 1960.

Gieysztor A., „Ornamenta regia” w Polsce XV wieku, w: Sztuka i ideologia XV wieku, red. P. Skubiszewski, Warszawa 1978, s. 155-163.

Gieysztor A., Spektakl i liturgia - polska koronacja królewska, w: Kultura elitarna i masowa w Polsce późnego średniowiecza, red. B. Geremek, Wrocław 1978, s. 9-23.

Godefroy T i D., Le cérémonial françois, Paris 1649.

Guenée B., Un meurtre, une société. L'assasinat du duc d'Orléans 23 novembre 1407, Paris 1992.

Guenée B., Lehoux F., Les Entrées royales françaises de 1328 à 1515, Paris 1968. 
Hallam E.M., Everard J., Francja w czasach Kapetyngów 987-1328, tłum. U. Kowalczyk, Warszawa 2006.

Hedeman A.D., Copies in context. The coronation of Charles V in his Grandes Chroniques de France, w: Coronations. Medieval and Early Modern Ritual, ed. J.M. Bak, Berkley-Los Angeles-Oxford 1990, s. 72-84.

Heers J., Fêtes, jeux et joutes dans les sociétés d'Occident à la fin du Moyen Âge, Paris 1971.

Jacquot J., La fête princière, w: Histoire des spectacles, Encyclopédie de la Pléiade, Paris 1965.

Henwood Ph., Administration et vie des collections d'orfèvrerie royales sous le règne de Charles VI (1380-1422), „Bibliothèque de l'École des Chartes”, 138, juillet-décembre 1980, s. 179-215.

Investitur- und Krönungsrituale. Herrschaftseinsetzungen im kulturellen Vergleich, hrsg. v. M. Steinicke, S. Weinfurter, Köln-Weimar-Wien 2005.

Jackson R.A., Le pouvoir monarchique dans la cérémonie du sacre et couronnement des rois de France, w: Représentation, pouvoir et royauté à la fin du Moyen Âge. Actes du colloque organisé par l'Université du Maine les 25 et 26 mars 1994, éd. J. Blanchard, Paris 1995, s. 237-251.

Jackson R.A., The Traité du sacre of Jean Golein, „Proceedings of the American Philosophical Society", 113, 1969, s. 305-324.

Jackson R.A., ,Vivat rex”. Histoire des sacres et des couronnements en France 13641825, Strasburg 1984.

Kantorowicz E.H., Dwa ciała króla. Studium ze średniowiecznej teologii politycznej, red. wyd. pol. J. Strzelczyk, Warszawa 2007.

Kantorowcz E., „Laudes regiae”. A Study in Liturgical Acclamations and Mediaeval Rulers Worship, Berkeley 1946.

Kintzinger M., „Coronam sustentare”. Krönung und Konsens in Frankreich und im deutschen Reich im Spätmittelalter, w: Ritualisierung politischer Willensbildung. Polen und Deutschland im hohen und späten Mittelalter, hrsg. v. W. Fałkowski, B. Schneidmüller, S. Weinfurter, Wiesbaden 2010, s. 47-63.

Klaniczay G., Źródła, formy i dziedzictwo sakralnego charakteru godności królewskiej w Europie, w: Świat średniowiecza. Studia ofiarowane Profesorowi Henrykowi Samsonowiczowi, red. A. Bartoszewicz i in., Warszawa 2010, s. 552-576.

Krawczuk W., Kancelaria koronna a ceremoniat dworski, w: „Theatrum ceremoniale” na dworze książat i królów polskich. Materiały z konferencji naukowej zorganizowanej przez Zamek Królewski na Wawelu i Instytut Historii Uniwersytetu Jagiellońskiego w dniach 23-25 marca 1998, red. M. Markiewicz, R. Skowron, Kraków 1999, s. 183-191. 
Krynen J., „Le mort saisit le vif”. Genèse médiévale du principe d'instantanéité de la succession royale française, „Journal des Savants”, juillet-décembre 1983, s. $187-$ 221.

Krynen J., Les légistes idiots politiques. Sur l'hostilité des théologiens à l'égard des juristes, en France, au temps de Charles V, w: Théologie et droit dans la science politique de l'État moderne. Actes de la table ronde organisée par l'École française de Rome avec le concours du CNRS, Rome 12-14 novembre 1987, Rome 1991, s. 171-198.

Krynen J., L'Empire du roi. Idées et croyances politiques en France XIII-XV siècle, Paris 1993.

Le Goff J., Człowiek średniowiecza, w: Człowiek średniowiecza, red. J. Le Goff, tłum. M. Radożycka-Paoletti, Warszawa-Gdańsk 1996, s. 7-50.

Le Goff J., Długie średniowiecze, tłum. M. Żurowska, Warszawa 2007.

Le Goff J., Kultura średniowiecznej Europy, tłum. H. Szumańska-Grossowa, Warszawa-Gdańsk 2002.

Le Goff J., Święty Ludwik, tłum. zbiorowe, Warszawa 2001.

Leguai A., Fondements et problèmes du pouvoir royal en France (autour de 1400), w: Das spätmittelalterliche Königtum im europäischen Vergleich, hrsg. v. R. Schneider, Sigmaringen 1987 (Vorträge und Forschungen Konstanzer Arbeitskreis für mittelalterliche Geschichte, 32), s. 41-58.

L'État ou le roi. Les fondation de la modernité monarchique en France (XIVe-XVII siècles), éd. N. Bulst, R. Descimon, A. Guerreau, Paris 1996.

Petit de Julleville L., Les mystères, t. 1, Paris 1880.

Maisel W., Archeologia prawna Europy, Warszawa-Poznań 1989.

Maisel W., Archeologia prawna Polski, Warszawa-Poznań 1982.

McKitterick R., Królestwa Karolingów. Władza - konflikty - kultura 751-987, tłum. B. Hlebowicz, M. Wilk, Warszawa 2011.

Martin H., Mentalités médiévales. Représenations collectives du XIe au XVe siècle, t. 2, Paris 2001.

Mentzel-Reuters A., Die goldene Krone. Entwicklungslinien mittelalterlicher Herrschaftssymbolik, „Deutsches Archiv für Erforschung des Mittelalters”, 60, 2004, s. 135-182.

Mérindol de Ch., Entrées royales et princière à la fin de l'époque médiévale: jeux de taxinomie, d'emblématique et de symbolique, w: Les entrées gloire et déclin d'un cérémonial. Actes du colloque tenu au château de Pau les 10 et 11 mai 1996, sous la présidence du Professeur Bernard Guenée, actes réunis par Christian Desplat et Paul Mironneau, Paris 1998, s. 27-47.

Nelson J. L., Inauguration Rituals, w: tejże, Politics and Ritual in Early Medieval Europe, London 1986, s. 283-307.

Pastoureau M., Średniowieczna gra symboli, tłum. H. Igalson-Tygielska, Warszawa 2006. 
Petit E., Entrée du roi Charles VI à Dijon sous Philippe-le-Hardi, fêtes et réjouissances en Bourgogne, février 1390, Dijon 1885.

Piech Z., Herrschaftszeichen und Staatssymbolik in der Monarchie der letzten Piasten (1320-1370), „Quaestiones Medii Aevii Novae”, 1, 1996, s. 43-76.

Piech Z., Monety, pieczęcie $i$ herby $w$ systemie symboli władzy Jagiellonów, Warszawa 2004.

Piech Z., Strój, insygnia i atrybuty książąt piastowskich do końca XIV wieku, „,Kwartalnik Historii Kultury Materialnej”, 38, 1990, cz 1, s. 3-35; cz. 2, 199-222.

Piech Z., Symbole władcy i państwa w monarchii Władysława Łokietka i Kazimierza Wielkiego, w: „Imagines potestatis”. Rytuaty, symbole i konteksty fabularne władzy zwierzchniej. Polska X-XVw (z przykładem czeskim i ruskim), red. J. Banaszkiewicz, Warszawa 1994, s. 117-150.

Pleszczyński A., Powołanie i koronacja króla niemieckiego od X do XIII wieku. Miejsca, ryty, insygnia -zarys problemu, w: Gnieźnieńskie koronacje królewskie i ich środkowoeuropejskie konteksty, red. J. Dobosz, M. Matla, L. Wietesko, Gniezno 2011, s. $59-73$.

Rigaudière A., Etat, pouvoir et administration dans la Practica aurea libellorum de Pierre Jacobi (vers 1311), w: Droits savants et pratiques françaises du pouvoir (XI $-X V^{e}$ siècle), éd. J. Krynen, A. Rigaudière, Bordeaux 1992, s. 161-210.

Rokosz M., Polskie insygnia koronacyjne w średniowiecznych fabułach, w: „Imagines potestatis”. Rytuaty, symbole i konteksty fabularne władzy zwierzchniej w Polsce $X-X V$ w. (z przykładem czeskim i ruskim), red. J. Banaszkiewicz, Warszawa 1994, s. $206-227$.

Roux J.-P., Król. Mity i symbole, tłum. K. Marczewska, Warszawa 1998.

Sawicki W., Rytuat sakry-koronacji królewskiej jako źródła prawa i ustroju państw średniowiecznej Europy, „Archiwa, Biblioteki i Muzea Kościelne”, 24, 1972, s. 279_ 293.

Scheidgen H., Die französische Thronfolge (987-1500). Der Ausschluß der Frauen und das salische Gesetz, Bonn 1976.

Schenk G.J., Zeremoniell und Politik. Herrschereinzüge im spätmittelalterlichen Reich, Köln-Weimar-Wien 2003 (Forschungen zur Kaiser- und Papstgeschichte des Mittelalters. Beihefte zu J. F. Böhmer, Regesta Imperii, 21).

Schmitt J.-Cl., Gest w średniowiecznej Europie, tłum. H. Zaremska, Warszawa 2006.

Schnith K., Krönung, w: Lexikon des Mittelalters, t. 5, 1991, szp. 1547-1549.

Schramm P.E., Der König von Frankreich: das Wesen der Monarchie vom 9. bis zum 16. Jahrhundert. Ein Kapitel aus der Geschichte des abendländischen Staates, 2 Bde., Weimar 1939, 2. Auf., Darmstadt 1960.

Schramm P.E., Der König von Frankreich: Wahl, Krönung, Erbfolge und Königsidee vom Anfang der Kapetinger (987) bis zum Ausgang des Mittelalters (Fortsetzung 
und Schluß), ,Zeitschrift der Savigny Stiftung für Rechtsgeschichte Kanonistische Abteilung", 26, 1937, s. 161-284.

Schramm P.E., Geschichte des englischen Königtums im Lichte der Krönung, Weimar 1937.

Schramm P.E., Herrschaftszeichen und Staatssymbolik. Beiträge zu ihrer Geschichte vom 3. bis zum 16. Jahrhundert, 3 Bde., Stuttgart 1954-1956 (Schriften der Monumenta Germaniae Historica).

Sobotka R., Powolywanie władcy w ,,Rocznikach” Jana Dtugosza, Warszawa 2005.

Struve T., Die Begründung monarchischer Herrschaft in der politischen Theorie des Mittelalters, „Zeitschrift für historische Forschung”, 23, 1996, s. 289-323.

Todière L.-P., Charles VI, les Armagnacs et les Bourguignons, Tours 1848.

Twining E.F., A History of the Crown Jewels of Europa, London 1960.

Twining E.F., European Regalia, London 1967.

Valensise M., Le sacre du roi: stratégie symbolique et doctrine politique de la monarchie française, „Annales. Économies, Sociétés, Civilisations”, 3, mai-juin 1986, s. 543577.

Zientara B., Świt narodów europejskich. Powstawanie świadomości narodowej na obszarze Europy pokarolińskiej, Warszawa 1985.

\section{STreszczenie}

W późnośredniowiecznej monarchii francuskiej koronacja królewska miała fundamentalne znaczenie w procesie powołania nowego króla. W sferze wizualnej można obserwować wzmocnienie jej charakteru ceremonialnego, co wynikało z potrzeby jaskrawej manifestacji ciągłości władzy królewskiej, potrzebnej w czasie kryzysu dynastycznego spowodowanego śmiercią króla. Wzrastało przywiązanie do symboli władzy dynastycznej. Ważne miejsce w ideologii władzy królewskiej miało miejsce, w którym dokonywano koronacji nowego króla. W przypadku Francji było to Reims. Przebieg koronacji odbywał się według ustalonego schematu. Ceremonia koronacyjna była manifestacją wyniesienia dynastii i związanych z tym faktem praw rodowych. W badanym okresie nastąpił wzrost znaczenia prawa krwi, które czyniło królewskiego syna prawowitym następcą. Do pełnej legitymizacji władzy potrzebował on jednak sakry królewskiej, która w sferze symbolicznej stwarzała poczucie kontynuacji. 


\title{
The Significance of the Royal Coronation in the Late Medieval France
}

\begin{abstract}
In the late-Medieval French Monarchy the royal coronation played a significant role in the process of appointing a new king. In its visual sphere a certain reinforcement of the ceremonial character may be noted, which was result of a need for a strong manifestation of the continuity of the royal power, indispensable in the times of the dynastic crisis caused by the death of the king. The symbols of the dynastic power became stronger. In the ideology of the royal power it was important where the coronation took place. In the case of France it was Reims. The coronation was organised according to a strict pattern. The coronation ceremony was a manifestation of the fact that the dynasty had been put on a pedestal and had acquired some new rights. In the period in question the role of the blood right became more important, and the royal son was the rightful heir to the throne. But to legitimise the power to the fullest he needed the royal anointment, which in the symbolic sphere created a sense of continuity.
\end{abstract}

